\title{
Simposio
}

\section{Genética eVolutiva de parásitos}

\section{Compared population genetics of pathogenic microorganisms (parasites, fungi, bacteria), epidemiological consequences}

\author{
Michel Tibayrenc \\ Infectious Diseases and Vectors, Ecology, Genetics, Evolution and Control, MIVEGEC/IDVEGEC, IRD, \\ La Paz, Bolivia
}

In this talk, I will insist one more time on the urgency to disrupt the distressing separation between molecular epidemiology and evolutionary biology. I will show how much population genetics and phylogenetic analysis can confer a considerable added value to all attempts to characterize strains and species of pathogens. A population genetics approach gives a convenient framework to all studies dealing with the genetic diversity of pathogens, including molecular epidemiology, clinical studies, design of drug/vaccine/molecular diagnosis, and experimental evolution.

The problems dealing with the mere definition of basic concepts such as species, subspecies or strains will be briefly summarized. Lastly, I will show the important contribution of molecular epidemiology to our knowledge on the basic biology of pathogens and will insist on the necessity not to separate the studies dealing with pathogens from those that concern the hosts, and the vectors in the case of vector-borne diseases.

Some telling examples will be taken in parasitic protozoa, bacteria and fungi, in order to underline the fact that these approaches are valuable, whatever may be the pathogen considered.

Recommended readings

1. Tibayrenc M, Kjellberg F, Ayala FJ. A clonal theory of parasitic protozoa: the population structure of Entamoeba, Giardia, Leishmania, Naegleria, Plasmodium, Trichomonas and Trypanosoma, and its medical and taxonomical consequences. Proc Nat Acad Sci USA. 1990;87:2414-8.

2. Tibayrenc M. Genetic epidemiology of parasitic protozoa and other infectious agents: the need for an integrated approach. Int J Parasitol. 1998;28:85104.

3. Tibayrenc M. Molecular epidemiology and evolutionary genetics of pathogens. In: Tibayrenc M, editor. Encyclopedia of infectious diseases: modern methodologies. New York: Wiley \& Sons; 2007. p. 337-55.

4. Tibayrenc M. Microbial molecular epidemiology: an overview. In: Caugant DA, editor. Methods in molecular biology: molecular epidemiology of microorganisms. New York: Humana Press; 2009. p. 1-12.

5. Tibayrenc M, Barnabé C, Telleria J. Reticulate evolution in Trypanosoma cruzi: medical and epidemiological implications. In: Telleria J, Tibayrenc $M$, editors. American trypanosomiasis: Chagas' disease. One hundred years of research. Elsevier Insights; 2010.

6. Tibayrenc M. Population genetics and molecular epidemiology of infectious diseases. In: Morand S, Beaudreau F, Cabaret J, de Rycke J, editos. New frontiers of molecular epidemiology of infectious diseases. Springer; 2010. En prensa.

\section{De la genética evolutiva de triatominos y de Trypanosoma cruzi a los sistemas epidemiológicos de la enfermedad de Chagas}

\author{
Simone Frédérique Brenière, Christian Barnabé \\ MIVEGEC, Université de Montpellier, IRD, Représentation en Bolivie, La Paz, Bolivia; \\ Laboratorio de Entomología Médica, Instituto Nacional de Laboratorios de Salud, La Paz, Bolivia \\ Es difícil emprender el estudio de los sistemas \\ epidemiológicos de la enfermedad de Chagas \\ (zoonosis parasitaria), dada la multitud de posibles \\ escenarios relacionados con la enorme bio- \\ diversidad de los agentes (vectores, parásitos, \\ reservorios mamíferos) participantes de los \\ ciclos de transmisión silvestres y domésticos. \\ Estos ciclos frecuentemente se superponen y se
}


encuentran en varias ecorregiones. Sin embargo, las investigaciones en filogenia y en genética de poblaciones de triatominos y de Trypanosoma cruzi, el agente de la enfermedad, ya han apoyado la comprensión de los sistemas epidemiológicos involucrados.

La enfermedad de Chagas está íntimamente ligada a la aparición del contacto hombre-vector (triatominos hematófagos) que tomó la forma de convivencia íntima en el hábitat humano, tras la adaptación (domesticación) de ciertas especies de vectores. En una primera etapa, parece lógico restringir el examen de los conocimientos de la genética de poblaciones (el vector y el parásito) a una sola especie, considerando su área de distribución. Esta presentación se ajustará en la superficie máxima de distribución de Triatoma infestans observada antes las acciones de los programas de control de vectores (www.ciesin. columbia.edu/docs/001-613/001-613.html; mapa 34). Esta área cubre la distribución de las poblaciones domésticas de $T$. infestans, donde este vector es o ha sido el principal agente responsable de la transmisión de la enfermedad de Chagas, la cual incluye la distribución predictiva de las poblaciones silvestres (1).

La revisión de los datos genéticos pasados y recientes de los vectores y parásitos se lleva a cabo sobre el rango de distribución de $T$. infestans. Estos datos también se revisan en el marco de recientes aportes:

1. descubrimiento de una distribución más amplia de las poblaciones silvestres de $T$. infestans (2-6),

2. en algunas áreas, el fracaso del control de las poblaciones domésticas de $T$. infestans $(7,8)$, y

3. la clasificación de consenso de T. cruzien seis grupos genéticos (DTU, discrete typing units, Tcl-TcVI) (9).

Estos datos podrían, tal vez, responder a las preguntas siguientes:

1. ¿cuál es la historia evolutiva de las poblaciones naturales de $T$. infestans?,

2. ¿cómo se ha adaptado $T$. infestans a los asentamientos humanos y cómo se ha expandido en muchas regiones?,

3. si el fenómeno de domesticación está asociado a una diferenciación genética entre poblaciones silvestres y domésticas,

4. si la estructura de poblaciones permite comprender los modos de dispersión (pasiva o activa) de los vectores,
5. en el contexto de control de vectores por insecticidas, ¿cuál es el origen de las poblaciones de $T$. infestans detectadas después del tratamiento (poblaciones residuales versus reinfestantes)?

6. ¿cuáles son las DTU de T. cruzi que circulan en los ciclos silvestres, ¿cuáles son las responsables de la enfermedad de Chagas, ¿cuál es la dinámica de estas DTU entre ambos ciclos?, y

7. finalmente, mediante los datos genéticos, ¿cómo podemos predecir la evolución próxima de la transmisión vectorial de la enfermedad de Chagas en su área de distribución?

Actualmente, los estudios de filogenia y de la estructura de las poblaciones de $T$. infestans se llevan a cabo utilizando los marcadores nucleares (ITS1 e ITS2, microsatélites) y mitocondriales (citocromo b y la citocromo oxidasa), que son considerados los más adecuados para los estudios de filogeografía intraespecie y de flujo genético entre poblaciones vecinas (escala microgeográfica) (10).

Sin embargo, pocos estudios combinan varios marcadores con las mismas poblaciones. Además, la comparación entre poblaciones silvestres y domésticas ha sido poco estudiada. Para cada marcador (ITS-2, citocromo b y la citocromo oxidasa I), nuestras secuencias y las depositadas en el banco, procedentes de poblaciones silvestres y domésticas, se analizan en una sola red de relaciones entre haplotipos.

La interpretación de estas redes, teniendo en cuenta la distribución geográfica y el origen ecológico de los haplotipos, permitirá proponer hipótesis sobre la evolución y la dispersión de $T$. infestans. La información obtenida por el estudio del polimorfismo de los microsatélites se limita todavía a pocos trabajos, pero la extrema estructuración observada entre poblaciones locales permite ya, analizar los movimientos de las poblaciones entre ecótopos vecinos en medio selvático o domestico $(7,11)$.

En cuanto al parásito, los datos genéticos de las cepas que circulan en el área de distribución de $T$. infestans son en su mayoría cepas domésticas, y se comparan con las cepas silvestres recientemente caracterizadas. Las cepas se pueden caracterizar ya sea después de su aislamiento en cultivo o directamente en los medios biológicos (tracto digestivo del vector, sangre y tejidos de mamíferos). Muchas cepas se caracterizaron después de su aislamiento en cultivo a partir de los vectores 0 
de sangre de pacientes chagásicos o después del xenodiagnóstico. Posteriormente, los métodos de detección directa por PCR se utilizaron para caracterizar muchas otras cepas silvestres y domésticas. Cada uno de estos métodos presenta sesgos de selección de ciertos genotipos frente a otros (12).

Todas las caracterizaciones realizadas hasta ahora por diferentes marcadores, se traducen en lo posible en términos de pertenencia a uno de los seis DTU actuales. La distribución geográfica de las DTU se analizará cuidadosamente según el origen silvestre o doméstico de las cepas y según los huéspedes. Algunos estudios muestran una estructuración de las DTU en nichos ecológicos, sin embargo, las relaciones entre las DTU y las poblaciones de $T$. infestans se analizaron en raras ocasiones. Entre las DTU, se encuentran algunas ancestrales (Tcl, Tcll y TclV Tcll), mientras que TcV y TcVI tienen un origen híbrido reciente (13). Además, sabemos que el flujo genético entre estas DTU es extremadamente bajo y que el modo de propagación de $T$. cruzi es principalmente clonal (14).

La síntesis propuesta permitirá analizar las relaciones entre la historia evolutiva de $T$. cruzi y la de $T$. infestans (diferenciación genética, expansión geográfica, domesticación, adaptación de $T$. cruzi a varios huéspedes) mediante la integración de los conocimientos de los tiempos respectivo de evolución de estas dos especies.

\section{Referencias}

1. Gorla D, Noireau F. Geographic distribution of Triatominae vectors in America. In: Telleria J, Tibayrenc M, editors. American trypanosomiasis Chagas' disease. Burlington: Elsevier; 2010. p. 20931.

2. Waleckx $E$, Depickère $S$, Salas $R$, Aliaga $C$, Monje $\mathrm{M}$, Calle $\mathrm{H}$, et al. New field discoveries of sylvatic Triatoma infestans throughout the bolivian Chaco: What is changing? Am J Trop Med Hyg. 2011.

3. Buitrago R, Waleckx E, Bosseno MF, Zoveda F, Vidaurre $P$, Salas $R$, et al. First report of widespread wild populations of Triatoma infestans (Reduviidae, Triatominae) in the valleys of La Paz, Bolivia. Am J Trop Med Hyg. 2010;82:574-9.

4. Ceballos LA, Piccinali RV, Berkunsky I, Kitron U, Gurtler RE. First finding of melanic sylvatic Triatoma infestans (Hemiptera: Reduviidae) colonies in the
Argentine Chaco. J Med Entomol. 2009;46:1195202.

5. Bacigalupo A, Torres-Pérez F, Segovia V, García A, Correa JP, Moreno L, et al. Sylvatic foci of the Chagas disease vector Triatoma infestans in Chile: description of a new focus and challenges for control programs. Mem Inst Oswaldo Cruz. 2006;105:63341.

6. Rolón M, Vega MC, Román F, Gómez A, Rojas de Arias A. First report of colonies of sylvatic Triatoma infestans (Hemiptera: Reduviidae) in the Paraguayan Chaco, using a trained dog. PLoS Negl Trop Dis. 2011;5:e1026.

7. Marcet PL, Mora MS, Cutrera AP, Jones L, Gurtler RE, Kitron U, et al. Genetic structure of Triatoma infestans populations in rural communities of Santiago del Estero, northern Argentina. Infect Genet Evol. 2008;8:835-46.

8. Quisberth S, Waleckx E, Monje M, Chang B, Noireau F, Breniere SF. "Andean" and "non-Andean" ITS-2 and mtCytB haplotypes of Triatoma infestans are observed in the Gran Chaco (Bolivia): population genetics and the origin of reinfestation. Infect Genet Evol. 2011 Mar 29.

9. Zingales B, Andrade SG, Briones MR, Campbell DA, Chiari E, Fernandes $O$, et al. A new consensus for Trypanosoma cruzi intraspecific nomenclature: second revision meeting recommends $\mathrm{Tcl}$ to $\mathrm{TcVI}$. Mem Inst Oswaldo Cruz. 2009;104:1051-4.

10. Mas-Coma S, Bargues MD. Populations, hybrids and the systematic concepts of species and subspecies in Chagas disease triatomine vectors inferred from nuclear ribosomal and mitochondrial DNA. Acta Trop. 2009;110:112-36.

11. Richer W, Kengne P, Cortez MR, Perrineau MM, Cohuet A, Fontenille D, et al. Active dispersal by wild Triatoma infestans in the Bolivian Andes. Trop Med Int Health. 2007;12:759-64.

12. Bosseno MFY, Vargas N, Breniere SF. Selection of Trypanosoma cruzi clonal genotypes (clone 20 and 39 ) isolated from Bolivian triatomines following subculture in liquid medium. Mem Inst Oswaldo Cruz. 2000;95:601-7.

13. Gaunt MW, Yeo M, Frame IA, Stothard JR, Carrasco $\mathrm{HJ}$, Taylor MC, et al. Mechanism of genetic exchange in American trypanosomes. Nature. 2003;421:936-9.

14. Tibayrenc M, Kjellberg F, Ayala FJ. A clonal theory of parasitic protozoa: the population structures of Entamoeba, Giardia, Leishmania, Naegleria, Plasmodium, Trichomonas, and Trypanosoma and their medical and taxonomical consequences. Proc Nat Acad Sci USA. 1990;87:2414-8. 


\title{
Evolución de la organización y mantenimiento de los telómeros en Trypanosomatidae
}

\author{
José Luis Ramírez, Riward Campelo, María Mercedes Galindo \\ Instituto de Estudios Avanzados, Ministerio del Poder Popular para la Ciencia y Tecnología de Venezuela, \\ Caracas, Venezuela
}

Los telómeros por mucho tiempo fueron considerados como simples extremos cromosómicos, sin embargo, tan temprano como 1953, Watson y Crick destacaban el problema de la replicación de la molécula de ADN en sus extremos, de ahí que estos extremos deberían de tener propiedades especiales.

Estas propiedades son ahora bien conocidas, entre ellas: evitar el acortamiento de los cromosomas en las rondas de replicación, evitar el reordenamiento de cromosomas y prevenir la degradación de estos extremos. Los telómeros de las células somáticas también constituyen parte del llamado reloj mitótico mediante el cual el número de divisiones de una determinada célula viene determinado por su longitud telomérica.

En años recientes se ha podido descubrir que el telómero se organiza de una manera muy especial agrupándose con proteínas específicas para constituir el telosoma. Aparte de lo mencionado anteriormente, el telómero puede ser una región en donde los organismos pueden llevar a cabo funciones de contingencia, tal es el caso de la levadura Sacharomyces cereviseae en cuyos telómeros se ubican las copias de los genes que determinan la sexualidad, Trypanosoma brucei y Plasmodium falciparum cuyos telómeros son un verdadero laboratorio para la evasión del ataque montado por la célula huésped (1).

En nuestros estudios hemos podido encontrar que organismos perteneciente al mismo género (Trypanosoma) o familia (Trypanosomatidae) taxonómica muestran variadas organizaciones, así, vamos desde el simple telómero de $T$. rangeli (2) en el cual no se identifica la agrupación de ninguna familia de genes de contingencia; en $T$. cruzi es todo lo contrario pues contiene varios miembros de la superfamilia gp 85, genes de los llamados Retrotransposon Hotspot Proteins, y el gen más grande del parásito la familia de Disperse Gene Family 1 (DGF-1) $(3,4)$.

Por otro lado, Leishmania muestra un telómero con una estructura muy peculiar con repeticiones insertadas por repeticiones de hexámeros y cubriendo grandes longitudes, antes de terminar en el extremo telomérico propiamente dicho (5). Previamente hemos demostrado que en Leishmania majorexiste una telomerasa muy activa que muestra una gran termorresistencia (6); recientemente esto lo hemos expandido a T. cruzi y hemos encontrado propiedades bastante similares, y creemos que la termorresistencia podría ser un reflejo de una estructura proteica especial que hace que en estos parásitos la actividad de la telomerasa sea más de proceso.

En este seminario discutiremos las distintas estrategias de evolución de los telómeros de Trypanosomatidae, y la dinámica para su mantenimiento.

\section{Referencias}

1. Barry J, Ginger ML, Burton P, McCulloch R. Why are parasite contingency genes often associated with telomeres? Int J Parasitol. 2003;33:29-45.

2. Chiurillo MA, Peralta A, Ramírez JL. Comparative study of Trypanosoma rangeliand Trypanosoma cruzi telomeres. Mol Biochem Parasitol. 2002;120:305-8.

3. Kim D, Chiurillo MA, El-Sayed N, Jones K, Santos MR, Porcile PE, Andersson B, Myler P, da Silveira $\mathrm{JF}$, et al. Telomere and subtelomere of Trypanosoma cruzi chromosomes are enriched in (pseudo)genes of retrotransposon hot spot and trans-sialidase-like gene families: the origins of $T$. cruzi telomeres. Gene. 2005;346:153-61.

4. Lander N, Bernal C, Díez N, Añez N, Docampo $\mathrm{R}$, Ramírez JL. Localization and developmental regulation of a dispersed gene family-1 (DGF-1) protein in Trypanosoma cruzi. Infect Immun. 2010;78:231-40.

5. Chiurillo MA, Beck AE, Devos T, Myler PJ, Stuart $\mathrm{K}$, Ramírez JL. (). Cloning and Characterization of Leishmania donovani telomeres. Exp Parasitol. 2000;94:248-8.

6. Galindo A, Rodríguez E, Rojas MG, Figarella K, Campelo R, Ramírez JL. Heat-activated and thermoresistant telomerase activity in Leishmania major Friedlin. Acta Trop. 2009;111:86-9. 


\title{
Towards defining the genomic diversity of Trypanosoma cruzi
}

\author{
Michael W. Gaunt \\ London School of Hygiene and Tropical Medicine, London, United Kingdom
}

The genomics sequencing projects of Trypanosoma cruzi (El-Sayed, et al., 2005; Franzen, et al,. 2011) have initiated the new era of parasitological research into the causative agent of a disease that is currently causing upwards of 11 million lifelong infections by a mechanism of infection which is currently unknown. One of the first applications of the T. cruzi genome was a new set of tools for population genomics and the continued development of population genomics methods has been gathering pace since the first draft genome of $T$. cruzi.

In our first population genomics approach performed using genome-wide microsatellite markers (Llewellyn, et al., 2009a; Llewellyn, et al., 2009b) we delineated a single subgroup $\mathrm{Tcl}$ to reveal the complex population structure of the zoonoses, clearly defining arboreal and terrestrial zoonoses (Llewellyn, et al., 2009b). The arboreal Tcl zoonoses appeared to reveal an allopatric population structure based on national boundaries, although I will demonstrate this not a precise description. This first genomics approach provides advantages for clinical studies which are traditionally restricted to assessing the human serological response and the oligo-loci approaches which define the genetic lineage (DTU) of $T$. cruzi (Brisse, Verhoef and Tibayrenc, 2001; Barnabe, Brisse and Tibayrenc, 2000).

Here we report the continued development of the genomics approach in T. cruzi population genetics through the use of DNA-DNA microarrays to identify housekeeping genes subject to intense levels of positive selection within a DTU. I used a microarray chip representing 4,000 housekeeping genes and therein identified 5 non-hybridization events which were the consequence of gross amino acid deletions and hyper-variable amino acid mutations, herein referred to as the "microarray (identified) housekeeping genes". One of the microarray housekeeping genes in $T$. cruzi coincided with the anomalous absence in the genome of core housekeeping genes within that metabolic pathway and could provide a clear explanation why so much selection pressure is placed on the remaining gene. This could be a broader model for understanding the apparent oxymoron of strong selection within parasite housekeeping genes.

The identification of positive selected single copy genes within a DTU provides a new set of loci for investigating the population structure of $T$. cruzi and has immediate application in a parasite where every single linkage disequilibrium analysis without exception defines strictclonality. Thus the microarray housekeeping genes identify recombination between strains within the DTU and could become the major strategy for defining rare recombination events through a phylogenetics approach (Gaunt, et al., 2003). Moreover, by coupling positive selection with our recently discovered multi-clonal genetic diversity of $T$. cruzi in marsupial hosts (Llewellyn, et al., 2011) (Llewellyn, et al., 2011) the genetics tools for understanding chronic infection are now available.

I will demonstrate that amino acid selection within housekeeping genes also occurs at a far greater level than has been previously thought between $T$. cruzi DTUs, although the result is not unexpected given the vastly shifting ecotopes between DTUs of a genetically diverse zoonose (Gaunt and Miles, 2000; Patterson and Gaunt, 2010).

I will conclude by briefly highlighting my current genomics methodology to amplify half the $T$. cruzi exome, a unique achievement within eukaryotic parasitology, and the update of the current goal of using this output in first population level genome sequencing project. Routine genome sequencing of $T$. cruzi isolates will define the final stage in this period of methodology (Llewellyn, et al., 2011) logical development and initiate the onset of posttranslation genomics.

\section{References}

1. Barnabe C, Brisse S, Tibayrenc M. Population structure and genetic typing of Trypanosoma cruzi, the agent of Chagas disease: a multilocus enzyme electrophoresis approach. Parasitology. 2000;120:513-26.

2. Brisse S, Verhoef J, Tibayrenc M. Characterisation of large and small subunit rRNA and mini-exon genes further supports the distinction of six Trypanosoma cruzi lineages. Int J Parasitol. 2001;31:1218-26.

3. El-Sayed NM, Myler PJ, Bartholomeu DC, Nilsson D, Aggarwal G, Tran AN, et al. The genome sequence of Trypanosoma cruzi, etiologic agent of Chagas disease. Science. 2005;309:409-15.

4. Franzen O, Ochaya S, Sherwood E, Lewis MD, Llewellyn MS, Miles MA, Andersson B. Shotgun sequencing analysis of Trypanosoma cruzi I Sylvio X10/1 and comparison with T. cruzi VI CL Brener. PLoS Negl Trop Dis. 2011;5:e984. 
5. Gaunt MW, Miles MA. The ecotopes and evolution of triatomine bugs (triatominae) and their associated trypanosomes. Mem Inst Oswaldo Cruz. 2000;95:55765.

6. Gaunt MW, Yeo M, Frame IA. Stothard JR, Carrasco HJ, Taylor MC, et al. Mechanism of genetic exchange in American trypanosomes. Nature. 2003;421:936-9.

7. Llewellyn MS, Lewis MD, Acosta N, Yeo M, Carrasco HJ, Segovia M, et al. Trypanosoma cruzi Ilc: phylogenetic and phylogeographic insights from sequence and microsatellite analysis and potential impact on emergent Chagas disease. PLoS Negl Trop Dis. 2009a;3:e510.

8. Llewellyn MS, Miles MA, Carrasco HJ, Lewis MD, Yeo M, Vargas J, et al. Genome-scale multilocus microsatellite typing of Trypanosoma cruzi discrete typing unit I reveals phylogeographic structure and specific genotypes linked to human infection. PLoS Pathog. 2009b;5:e1000410.

9. Llewellyn MS, Rivett-Carnac JB, Fitzpatrick S, Lewis MD, Yeo M, Gaunt MW, Miles MA. Extraordinary Trypanosoma cruzi diversity within single mammalian reservoir hosts implies a mechanism of diversifying selection. Int J Parasitol. 2011;41:609-14.

10. Patterson JS, Gaunt MW. Phylogenetic multi-locus codon models and molecular clocks reveal the monophyly of haematophagous reduviid bugs and their evolution at the formation of South America. Mol Phylogenet Evol. 2010;56:608-21.

\title{
Virulence shift in a sexual clade of wild Toxoplasma gondii infecting marine mammals
}

\author{
N. Sundar ${ }^{1}$, M. A. Miller², J. M. Wendte ${ }^{1}$, P. A. Conrad ${ }^{3}$, N. Miller ${ }^{4}$, E. R. James ${ }^{5}$, P. Keeling ${ }^{5}$, \\ D. S. Roos ${ }^{4}$, M. E. Grigg ${ }^{1}$ \\ ${ }^{1}$ Laboratory of Parasitic Diseases, NIAID, National Institutes of Health, Bethesda, MD, USA \\ ${ }^{2}$ California Department of Fish and Game, Santa Cruz, CA, USA \\ ${ }^{3}$ School of Veterinary Medicine, University of California, Davis, CA, USA \\ ${ }^{4}$ Department of Biology, University of Pennsylvania, Philadelphia, PA, USA \\ ${ }^{5}$ Department of Botany, University of British Columbia, Vancouver, BC, Canada
}

Waterborne outbreaks of coccidian parasites such as Toxoplasma gondii are increasingly causing fatal disease in marine wildlife. Using population genetic and molecular methods to study the evolution, emergence and transmission of pathogenic strains of Toxoplasma sp., our work has identified a marine invasion of new genetic variants produced when two parasites mate inside their definitive felid hosts. Population expansions of felids near marine estuarine environments have led to increased deposition of highly infectious oocysts and widespread exposure of marine wildlife to these pathogenic pollutagens after storm events.

We have obtained Toxoplasma sp. isolates from Harbor Seals, California sea lions, and 80 sea otters since 1998. Based on multi-locus PCR-DNA sequencing at 20 polymorphic genes across all 14 chromosomes, two distinct lineages were identified: type II and a new clade of strains, called type X (also referred to as haplogroup 12), that possess distinct alleles from archetypal strains at the majority of loci sequenced.

Over $72 \%$ of marine mammal Toxoplasma sp. infections were type $X$. Type $X$ strains have also been identified infecting a variety of terrestrial animals in the United States, including humans and coastal bobcats and mountain lions.

Whole genome shotgun sequencing has identified that type $X$ is an admixture of strains from a cross between a type II strain and a sylvatic line we now refer to as gamma $(\gamma)$. When assayed through mice, a distinct subset of type $X$ strains were highly virulent $\left(\mathrm{LD}_{100}=1\right.$ parasite).

The genetic basis for the altered virulence patterns among type $X$ strains is currently being assessed and will be presented. 